\title{
Production, uses and cultivars of common buckwheat in Japan: An overview
}

\author{
Seisuke MOTONISHI ${ }^{1}$, Sakio TSUTSUI ${ }^{1}$, Tetsuo MIKAMI ${ }^{1}$ *
}

Received April 07, 2018; accepted September 17, 2018.

Delo je prispelo 07. aprila 2018, sprejeto 17. septembra 2018.

\begin{abstract}
Common buckwheat (Fagopyrum esculentum Moench) has attracted much attention due to its high nutritional value and medicinal properties. The crop has a long history of cultivation in Japan, and today, it is used mostly for manufacturing soba noodles which are quite popular in Japanese cuisine. Cultivation of common buckwheat in the country decreased gradually until the 1970 's, but has started to increase again in recent years. In this paper, we provide an overview of common buckwheat production in Japan with emphasis on the agronomic characteristics of representative Japanese cultivars and landraces.
\end{abstract}

Key words: agronomic characteristics; breeding; common buckwheat; cultivar; genetic diversity; landrace; soba noodles

\section{IZVLEČEK}

\section{PRIDELAVA, UPORABA IN SORTE NAVADNE AJDE NA JAPONSKEM: PREGLED}

Navadna ajda (Fagopyrum esculentum Moench) je pritegnila veliko pozornosti zaradi svoje velike hranilne vrednosti in zdravilnih lastnosti. Poljščina ima dolgo zgodovino gojenja na Japonskem in se danes največ uporablja za izdelavo "soba" rezancev, ki so zelo popularni v japonski kuhinji. Gojenje navadne ajde je $\mathrm{v}$ državi postopoma upadalo do sedemdesetih let prejšnjega stoletja, a je začelo v zadnjih letih spet naraščati. $\mathrm{V}$ prispevku je podan pregled pridelave navadne ajde na Japonskem s poudarkom na agronomskih lastnostih reprezentativnih japonskih sort in lokalnih zvrsti.

Ključne besede: navadna ajda; agronomske lastnosti; žlahtnenje; sorta; genetska raznolikost; lokalne zvrsti; soba rezanci

\section{INTRODUCTION}

Common buckwheat (Fagopyrum esculentum Moench), a member of the Polygonaceae family, has been widely grown for human consumption in Japan (Mazza, 1988; Ohnishi, 1988; Kishima et al., 1995; Murai \& Ohnishi, 1996). The crop is not a cereal, but its fruits are expediently classified among the cereal grains because of their similar usage. In fact, buckwheat flour is commonly employed in combination with wheat flour to prepare buckwheat noodles (soba noodles), a popular Japanese dish.

The history of buckwheat cultivation goes back to very ancient times in Asia (Murai \& Ohnishi, 1996; Jacquemart et al., 2012). It is now broadly accepted that common buckwheat was initially domesticated in the northwest part of the Yunnan province in China (Murai \& Ohnishi, 1996). This crop subsequently spread to Asian countries through two main routes (Murai \& Ohnishi, 1996). The first route crossed the Himalayan region and Tibet, and the second ended up in Japan through Northern China. Available evidence suggests that common buckwheat was introduced into Japan via the Korean peninsula from China (Nagatomo, 1984; Ohnishi, 1995; Murai \& Ohnishi, 1996). The crop became popular primarily due to its ability to grow well on marginal, infertile land as well as its rapid growth habit. When buckwheat first appeared in records in Japan in the $8^{\text {th }}$ century, it had already been cultivated extensively as a catch crop (Shinoda, 1978; Murai \& Ohnishi, 1996).

Although numerous local buckwheat landraces were grown in Japan at one time, common buckwheat culture in this country is currently dominated by only a small number of cultivars (http://www.tokusanshubyo.or.jp/jouhoushi/tokusanshu byo-26.pdf). In this paper, we review literature to provide an overview of common buckwheat production

1 Hokkaido Agricultural Laboratory for Business Development, Eniwa, 061-1405, Japan *Corresponding author: tm-mars@ fgbb.jp 
in Japan. Emphasis is placed on the agronomic characteristics of main Japanese cultivars and landraces. The expectation is that the synthesized information from this review will be useful for researchers and other stakeholders interested in the common buckwheat crop in Japan.

\section{COMMERCIAL PRODUCTION}

According to FAO statistics, the world buckwheat production in 2016 was approximately 2,396,000 metric tonnes (FAO, 2017). Russia and China were the largest producers, collectively accounting for ca. $65 \%$ of global production that year. Japan ranked tenth in total buckwheat production (FAO, 2017).

In Japan, buckwheat production reached a maximum (139,000 tonnes from 165,000 hectares) in 1907 (Suzuki, 2003). Thereafter, it continuously declined until the 1970's (e.g., 18,000 tonnes from 18,000 hectares in 1975), because a number of farmers shifted their acreage from lower-yielding buckwheat to higheryielding crops such as rice (Suzuki, 2003). In recent years, however, buckwheat acreage and yield have started to increase again. As shown in Table 1, average production per year, from 2012 to 2016 inclusive, was ca. 34,500 tonnes (MAFF, 2017). This recovery tendency is undoubtedly due to the Japanese government subsidies to farmers who grow buckwheat, with the aim of decreasing the amount of excessively produced rice. It should also be added that Japan imports $65-75 \%$ of its domestic demand, mostly from China and the United States (MAFF, 2017).

Table 1: Production and cultivation area of buckwheat in Japan. Source: MAFF. (2017)

\begin{tabular}{|l|l|l|l|l|l|}
\hline & 2012 & 2013 & 2014 & 2015 & 2016 \\
\hline Cultivation area (ha) & 61,000 & 61,400 & 59,900 & 58,200 & 60,600 \\
\hline Total harvest (t) & 44,600 & 33,400 & 31,100 & 34,800 & 28,500 \\
\hline
\end{tabular}

\section{USES}

Although the small leaves and shoots are also edible, common buckwheat fruits, generally considered as seeds are by far the most important for Japanese consumers. Harvested seeds are dehulled after drying, and the remaining part, called groats, is ground into flour. As mentioned above, buckwheat flour has traditionally been used in the preparation of soba noodles. The noodles play a major role in Japanese cuisine and are easily available in dried form in supermarkets throughout the country. Soba noodle dishes are served either cold with dipping sauce, or in hot broth as noodle soup.
Common buckwheat is also processed to various valueadded products such as cakes, tea, beer and other local alcoholic beverages. The crop produces good quality of honey, whereas several buckwheat extracts are utilized for pharmacological and dietetics purposes (Bavec et al., 2002; Jacquemart et al., 2012; Kreft et al., 2016). In particular, flavonoids (mainly rutin and quercetin), Dchiro-inositol and proteins derived from buckwheat are in increasing demand, due to their biological and physiological activities including anti-oxidant, antiinflammation and anti-hypertension properties (Jacquemart et al., 2012; Suzuki et al., 2012a; GiménezBastida \& Zieliński, 2015; Kreft et al., 2016).

\section{JAPANESE CULTIVARS}

Common buckwheat exhibits a floral dimorphism known as distyly: each individual plant in a given cultivated population bears either pin (long pistil and short stamens) or thrum (short pistil and long stamens) flowers (Campbell, 1997; Woo et al., 2010). Both flower morphs are self-incompatible, and interfertile. Seed production thus depends upon insects and wind that mediate cross-pollination between pin and thrum plants. Owing to obligatory outcrossing characteristics, each cultivated population is expected to maintain a large amount of plant-to-plant variation. Almost all of the Japanese common buckwheat cultivars released to date have been developed from selection within locally grown landraces, and are not the products of controlled crosses.

Japanese common buckwheat cultivars are generally classified into three agroecotypes: summer, autumn (late-summer), and intermediate types (Matano \& Ujihara, 1979; Namai, 1990; Hara et al., 2011; Hara \& 
Ohsawa, 2013). Summer-type cultivars are mainly grown in high-latitude regions, and seem non-sensitive to photoperiod. Autumn-type cultivars are grown in low-latitude regions and behave as facultative short-day plants. Intermediate-type cultivars show moderate photoperiodic sensitivity. The agroecotype and principal characteristics of representative Japanese buckwheat cultivars are presented in Table 2.

The important problem in common buckwheat cultivation is low and unstable yield. Breeding efforts have been made to improve seed yields. Most of the Japanese cultivars listed in Table 2 are actually largerseeded genotypes (a grain mass of 32-38 g/1,000 seeds, http://www.maff.go.jp/tohoku/seisan/soba/pdf/25soba manual.) with better grain yields. Additionally, common buckwheat reaches lower plant height and has been considered as more resistant to lodging. The cultivar 'Kitawasesoba' is an example of such a plant habit (Inuyama et al., 1994, see Table 2). In this crop, indeterminate seed setting and remarkable seed shattering make it difficult to determine the appropriate time for harvesting. It goes without saying that seed shattering causes serious yield losses. To overcome the problems there has been increasing emphasis upon the improvement of seed shattering and uniformity in ripening among seeds (Funatsuki et al., 2000; Matsui et al., 2003, 2004; Suzuki et al., 2012b).

Table 2: List of representative common buckwheat cultivars grown in Japan

\begin{tabular}{|l|l|}
\hline $\begin{array}{l}\text { Cultivar } \\
\text { (Agroecotype) }\end{array}$ & Parentage and agronomic characteristics \\
\hline $\begin{array}{l}\text { Kitawasesoba } \\
\text { (Summer) }\end{array}$ & $\begin{array}{l}\text { Selected from a landrace 'Botansoba' and released in 1989. High-yielding and } \\
\text { early maturing cultivar with lodging resistance and good market acceptability. }\end{array}$ \\
\hline $\begin{array}{l}\text { Hashikamiwase } \\
\text { (Intermediate) }\end{array}$ & $\begin{array}{l}\text { Selected from a locally grown buckwheat population and released in 1933. } \\
\text { Large-seeded, nice flavor when cooked, but easy seed-shattering at maturity. }\end{array}$ \\
\hline $\begin{array}{l}\text { Dewakaori } \\
\text { (Intermediate) }\end{array}$ & $\begin{array}{l}\text { Developed in 1995 using a locally grown landrace 'Mogamiwase' for increased } \\
\text { grain mass and improved taste. Moderately resistant to lodging. }\end{array}$ \\
\hline $\begin{array}{l}\text { Hitachi-akisoba } \\
\text { (Intermediate) }\end{array}$ & $\begin{array}{l}\text { Produced in 1985 using a local landrace as breeding material. Large-seeded and } \\
\text { high-yielding cultivar with good taste. }\end{array}$ \\
\hline $\begin{array}{l}\text { Shinano No.1 } \\
\text { (Intermediate) }\end{array}$ & $\begin{array}{l}\text { Selected from a locally grown landrace and released in 1944. High-yielding } \\
\text { genotype with good taste, but having the problem with lodging. }\end{array}$ \\
\hline $\begin{array}{l}\text { Oonozairai } \\
\text { (Autumn) }\end{array}$ & $\begin{array}{l}\text { High-yielding landrace having desirable flavor and sweetness upon cooking, and } \\
\text { good market acceptability. }\end{array}$ \\
\hline $\begin{array}{l}\text { Miyazakiootsubu } \\
\text { (Autumn) }\end{array}$ & $\begin{array}{l}\text { Tetraploid cultivar bred using a locally grown landrace and released in 1982, } \\
\text { having increased lodging resistance, but the problem with late maturity. }\end{array}$ \\
\hline
\end{tabular}

\section{LANDRACE 'BOTANSOBA'}

Over the past two to three decades, Japanese buckwheat landraces have been replaced with improved cultivars that give better groats yields and are more or less genetically uniform (Campbell, 1997, 2003; Woo et al., 2010). Nevertheless, it is quite interesting to observe that a small number of landraces are still being cultivated to a limited extent. The landrace 'Botansoba' is a case in point (Figure 1). 'Botansoba' was selected by the National Agricultural Research Center for Hokkaido Region, Japan from a heterogeneous population grown in Date town (latitude: $42^{\circ} 28^{\prime} \mathrm{N}$, longitude: $140^{\circ} 51^{\prime} \mathrm{E}$ ) in Hokkaido, and released for cultivation in 1930 (Campbell, 2003). This landrace exhibited the high adaptability to local agroclimatic conditions in northern Japan, and was the most cultivated in the Hokkaido district until the release of an advanced cultivar 'Kitawasesoba (see Table 2)' in 1989 (Inuyama et al., 1994; Campbell, 1997).
'Botansoba' has problems such as higher plant height, and low and unstable yield (as seen in Table 3, 'Botansoba' had apparently higher plant height and lower grain yields than 'Kitawasesoba'), but has high market acceptability; soba noodles made from 'Botansoba' flour actually gain a good reputation for their delicate, appetizing flavor as well as for their characteristic sweetness. The content of rutin in the groats of 'Botansoba' was found to range from 15.5 to $18.6 \mathrm{mg} 100 \quad \mathrm{~g}^{-1} \quad$ (S. Motonishi, unpublished), comparable to that of Japanese common buckwheat cultivars such as 'Kitawasesoba' and 'Shinano No.1' (Kitabayashi et al., 1995).

The seeds of 'Botansoba' have been multiplied not by seed certifying agencies but by farmers for a long time. It is thus reasonable to assume that the farmers in question have not always used the seed-parent plant population large enough to represent a true sampling of the genetic variation present in the source population of 
'Botansoba'. If the landrace has experienced the genetic bottleneck because of a too small population size, the genetic variation contained in the source population is perhaps fragmented and distributed over the several germplasm resources holdings today. This surmise was supported by morphological characterization of 'Botansoba' stocks preserved in four different seed sources: Breeder's stock, NCSS stock, Urausu-town stock and S-town stock (Honda et al., 2004). As shown in Table 3, S-town stock (source \#4) obviously differed from Breeder's stock (source \#1) in terms of plant height and days to maturity, whereas no apparent differences were observed among NCSS stock (source \#2), Urausu-town stock (source \#3) and Breeder's stock for these two characteristics. Moreover, the grain yield of S-town stock was revealed to be higher than that of Breeder's stock. Meanwhile, we cannot rule out the possibility that such differences may be attributable to inter-varietal cross pollination (Adhikari \& Campbell, 1998). In order to preserve the purity of genetic resources such as 'Botansoba', the seeds need to be multiplied using effective population size of seed-parent plants, under a suitable isolation procedure (Adhikari \& Campbell, 1998).
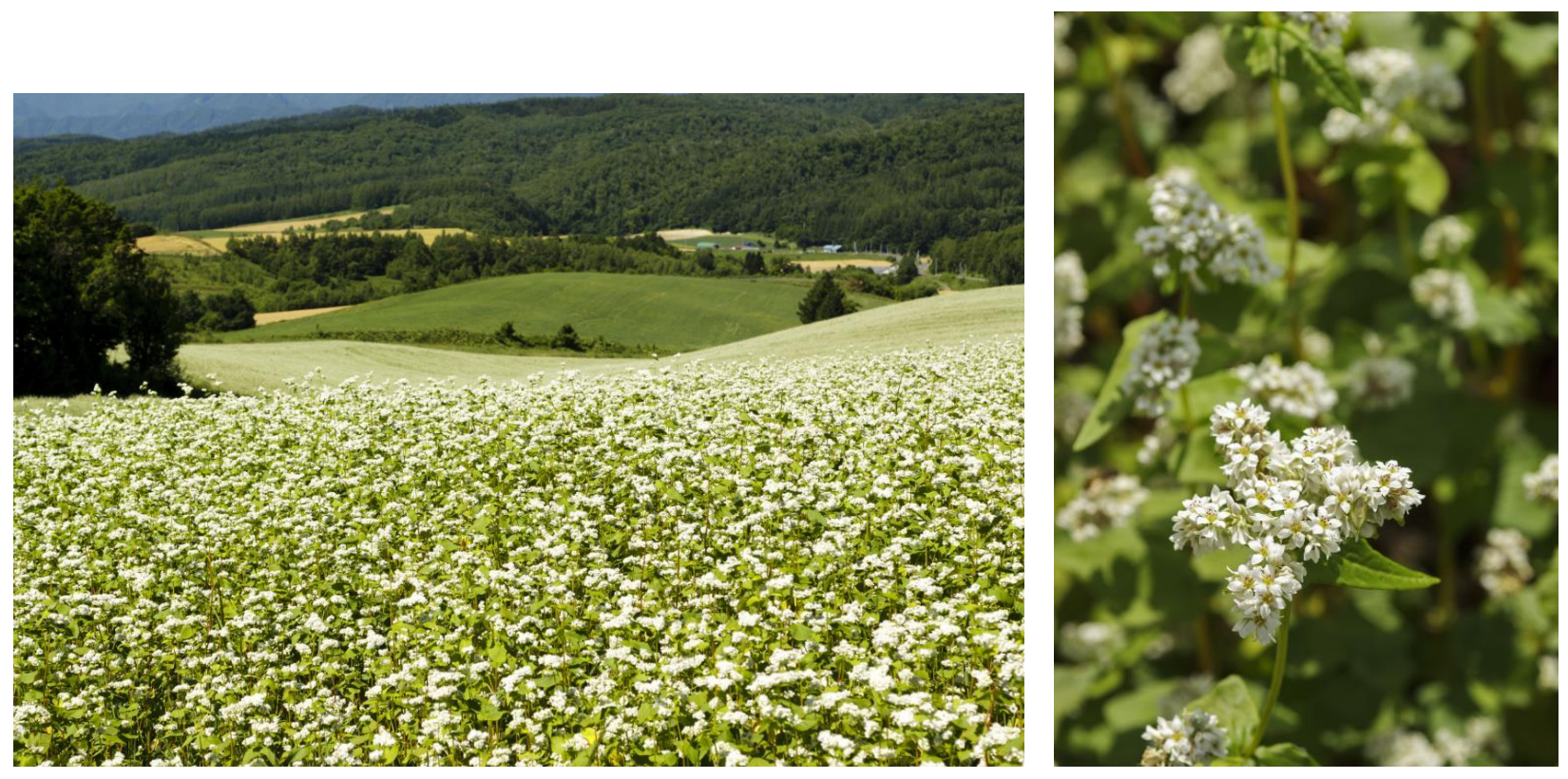

Figure 2: Landrace 'Botansoba'. Flowering on a farm (left panel) and inflorescence (right panel)

Table 3: Agronomic characteristics of landrace 'Botansoba' preserved in four different seed sources and an advanced cultivar 'Kitawasesoba'. Source: Y. Honda et al. (2004)

\begin{tabular}{|l|l|l|l|l|l|}
\hline Genotype & $\begin{array}{l}\text { Days to } \\
\text { maturity }\end{array}$ & $\begin{array}{l}\text { Plant height } \\
(\mathrm{cm})\end{array}$ & $\begin{array}{l}\text { Number of } \\
\text { branches }\end{array}$ & $\begin{array}{l}\text { Grain yields } \\
\mathrm{kg} \mathrm{a}^{-1}\end{array}$ & $\begin{array}{l}1,000 \text {-seed } \\
\text { mass (g) }\end{array}$ \\
\hline Botansoba & & & & & \\
Seed source \#1: Breeder's stock* & 100 & 142 & 2.7 & 11.1 & 27.0 \\
Seed source \#2: NCSS** & 100 & 146 & 3.0 & 9.5 & 27.2 \\
Seed source \#3: Urausu town & 100 & 144 & 3.1 & 11.7 & 25.8 \\
Seed source \#4: S town & 107 & 161 & 3.0 & 13.8 & 25.7 \\
\hline Kitawasesoba & & & & & \\
Seed source: NARO*** & 90 & 123 & 2.3 & 15.5 & 28.3 \\
\hline
\end{tabular}

The study was carried out in 2004 at the experimental field located in Memuro town (latitude: $42^{\circ} 53^{\prime} \mathrm{N}$, longitude: $\left.143^{\circ} 03^{\prime} \mathrm{E}\right)$, Hokkaido. Seeds were sown on 3 June.

* Hokkaido Prefectural Plant Genetic Resources Center, Japan

** National Center for Seeds and Seedlings, Japan

*** National Agriculture and Food Research Organization, Hokkaido Agricultural Research Center, Japan 


\section{CONCLUDING REMARKS}

In conclusion, two additional points merit comment. First, Tartary buckwheat (Fagopyrum tatacicum (L.) Gaertn.), a close relative of common buckwheat, is also cultivated in many areas of the world (Campbell, 1997; Senthilkumaran et al., 2008; Li et al., 2012). This crop, comparing to common buckwheat, is less widespread because of its bitter taste; in Japan, Tartary buckwheat was harvested from only 95 hectares with a total yield of 114 tonnes in 2015 (http://www.tokusanshubyo.or.jp/jouhoushi/tokusanshu byo-26.pdf). However, increased interest has been shown for human consumption of Tartary buckwheat due to some of its components that are very beneficial to human health. For instance, recent evidence indicates that the seed rutin content is approximately 100 times higher in Tartary buckwheat than in common buckwheat (Ikeda et al., 2012; Suzuki et al., 2014). Attempts have been made to improve Tartary buckwheat in Japan, resulting in the development of a promising Tartary buckwheat cultivar 'Manten-Kirari', whose flour is rutin-rich and lacks bitterness (Suzuki et al., 2014).
Secondly, buckwheat breeding is a recent endeavor when compared with breeding efforts devoted to major cereals. The use of molecular markers that are tightly linked to commercially important traits is now a widely accepted approach to help expedite the development of improved cultivars (Woo et al., 2010). In common buckwheat, studies have been performed to develop such markers as amplified fragment length polymorphism (AFLP) markers (Yasui et al., 2004), simple sequence repeat (SSR) markers (Konishi \& Ohnishi, 2006), expressed sequence tag (EST) markers (Hara et al., 2011), and array-based markers (Yabe et al., 2014). As far as we know, however, the markerassisted selection approach of the buckwheat crop is still in its infancy. Most recently, Yasui et al. (2016) have generated a draft assembly of the buckwheat genome using next-generation sequencing technology. They have also identified novel candidate genes involved in dimorphic self-incompatibility of the crop. Provided that the substantial buckwheat genome data-base is constructed, genomics-assisted approach will accelerate the genetic improvement of buckwheat.

\section{ACKNOWLEDGEMENTS}

We thank Mr. Makoto Nakamura (Managing Director, Hokkaido Agricultural Laboratory for Business Development) for support throughout this work. We are deeply indebted to Dr. Yutaka Honda (National
Agriculture and Food Research Organization) for valuable comments. The photos (Figure 1) were taken at a farm of Mr. Satoshi Inoue, located in Furano town (latitude: $43^{\circ} 27^{\prime} \mathrm{N}$, longitude: $142^{\circ} 48^{\prime} \mathrm{E}$ ), Hokkaido.

\section{REFERENCES}

Adhikari, K.N., Campbell, C.G. (1998). Natural outcrossing in common buckwheat. Euphytica, 102, 233-237. doi:10.1023/A:1018365210463

Bavec, F., Pušnik, S., Rajčan, I. (2002). Yield performance of two buckwheat genotypes grown as a full-season and stubble-crop. Rostlinná Výroba, 48, 351-355.

Campbell, C.G. (1997). Buckwheat, Fagopyrum esculentum Moench. Promoting the conservation and use of underutilized and neglected crops. 19. Institute of Plant Genetics and Crop Plant Research, Gatersleben/International Plant Genetic Resources Institute, Rome, Italy.

Campbell, C.G. (2003). Buckwheat crop improvement. Fagopyrum, 20, 1-6.

FAO. (2017). FAOSTAT database. Retrieved from http://www.fao.org/faostat/en/\#home

Funatsuki, H., Maruyama-Funatsuki, W., Fujino, K., Agatsuma, M. (2000). Ripening habit of buckwheat.

\section{Crop Science, $\quad 40, \quad 1103-1108$. doi:10.2135/cropsci2000.4041103x}

Giménez-Bastida, J.A., Zieliński, H. (2015). Buckwheat as a functional food and its effects on health. Journal of Agricultural and Food Chemistry, 63, 7896-7913. doi:10.1021/acs.jafc.5b02498

Hara, T., Iwata, H., Okuno, K., Matsui, K., Ohsawa, R. (2011). QTL analysis of photoperiod sensitivity in common buckwheat by using markers for expressed sequence tags and photoperiod-sensitivity candidate genes. Breeding Science, 61, 394-404. doi:10.1270/jsbbs.61.394

Hara, T., Ohsawa, R. (2013). Accurate evaluation of photoperiodic sensitivity and genetic diversity in common buckwheat under a controlled environment. Plant Production Science, 16, 247-254. doi:10.1626/pps.16.247

Honda, Y., Mukasa, Y., Suzuki, T. (2004). Traits of special local varieties in common buckwheat. Report of the Hokkaido Branch, the Japanese Society of Breeding 
and Hokkaido Branch, the Crop Science Society of Japan, 45, 53-54. (in Japanese)

Ikeda, K., Ikeda, S., Kreft, I., Rufa, L. (2012). Utilization of Tartary buckwheat. Fagopyrum, 29, 27-30.

Inuyama, S., Honda, Y., Furuyama, S., Kimura, M., Kasano, H. (1994). The breeding and characteristics of a buckwheat cultivar, 'Kitawasesoba'. Research Bulletin of the Hokkaido National Agricultural Experiment Station, 159, 1-10. (in Japanese)

Jacquemart, A.-L., Cawoy, V., Kinet, J.-M., Ledent, J.-F., Quinet, M. (2012). Is buckwheat (Fagopyrum esculentum Moench) still a valuable crop today? The European Journal of Plant Science and Biotechnology, 6, 1-10.

Kishima, Y., Ogura, K., Mizukami, K., Mikami, T., Adachi, T. (1995). Chloroplast DNA analysis in buckwheat species: phylogenetic relationships, origin of the reproductive systems and extended inverted repeats. Plant Science, 108, 173-179. doi:10.1016/0168-9452(95)04130-M

Kitabayashi, H., Ujihara, A., Hirose, T., Minami, M. (1995). Varietal differences and heritability for rutin content in common buckwheat, Fagopyrum esculentum Moench. Breeding Science, 45, 75-79. doi:10.1270/jsbbs1951.45.75

Konishi, T., Ohnishi, O. (2006). A linkage map for common buckwheat based on microsatellite and AFLP markers. Fagopyrum, 23, 1-6.

Kreft, I., Wieslander, G., Vombergar, B. (2016). Bioactive flavonoids in buckwheat grain and green parts. In M. Zhou, I. Kreft, S.-H. Woo, N. Chrungoo, G. Wieslander (Eds.), Molecular breeding and nutritional aspects of buckwheat (pp. 161-167). London: Academic Press. doi:10.1016/B978-0-12-803692$1.00012-2$

Li, C., Kobayashi, K., Yoshida, Y., Ohsawa, R. (2012). Genetic analyses of agronomic traits in Tartary buckwheat (Fagopyrum tataricum (L.) Gaertn.). Breeding Science, 62, 303-309. doi:10.1270/jsbbs.62.303

MAFF (Ministry of Agriculture, Forestry and Fisheries, Japan). (2017). Statistics of buckwheat production. Retrieved from http://www.maff.go.jp/j/tokei/sokuhou/tokuteisakumotu/h28/soba/index.html (in Japanese)

Matano, T., Ujihara, A. (1979). Agroecological classification and geographical distribution of the common buckwheat, Fagopyrum esculentum $\mathrm{M}$. in the East Asia. Japan Agricultural Research Quarterly, 13, 157-162.

Matsui, K., Tetsuka, T., Hara, T. (2003). Two independent gene loci controlling non-brittle pedicels in buckwheat. Euphytica, 134, 203-208. doi:10.1023/B:EUPH.0000003911.70493.cd
Matsui, K., Kiryu, Y., Komatsuda, T., Kurauchi, N., Ohtani, T., Tetsuka, T. (2004). Identification of AFLP markers linked to non-seed shattering locus (sht 1$)$ in buckwheat and conversion to STS markers for markerassisted selection. Genome, 47, 469-474. doi:10.1139/g04-007

Mazza, G. (1988). Lipid content and fatty acid composition of buckwheat seed. Cereal Chemistry, 65, 122-126.

Murai, M., Ohnishi, O. (1996). Population genetics of cultivated common buckwheat, Fagopyrum esculentum Moench. X. Diffusion routes revealed by RAPD markers. Genes and Genetic Systems, 71, 211218. doi:10.1266/ggs.71.211

Nagatomo, T. (1984). Scientific considerations on buckwheat. Tokyo: Shincho-sha. (in Japanese)

Namai, H. (1990). Pollination biology and reproductive ecology for improving genetics and breeding of common buckwheat, Fagopyrum esculentum (1). Fagopyrum, 10, 23-46.

Ohnishi, O. (1988). Population genetics of cultivated common buckwheat, Fagopyrum esculentum Moench. VII. Allozyme variability in Japan, Korea, and China. Japanese Journal of Genetics, 63, 507-522. doi:10.1266/jjg.63.507

Ohnishi, O. (1995). Discovery of new Fagopyrum species and its implication for the studies of evolution of Fagopyrum and of the origin of cultivated buckwheat. Current Advances in Buckwheat Research, 6, 175-190.

Senthilkumaran, R., Bisht, I.S., Bhat, K.V., Rana, J.C. (2008). Diversity in buckwheat (Fagopyrum spp.) landrace populations from north-western Indian Himalayas. Genetic Resources and Crop Evolution, 55, 287-302. doi:10.1007/s10722-007-9234-5

Shinoda, O. (1978). History of Chinese foods. Tokyo: Yasaka-shoboh. (in Japanese)

Suzuki, I. (2003). Production and usage of buckwheat grain and flour in Japan. Fagopyrum, 20, 13-16.

Suzuki, T., Mukasa, Y., Morishita, T., Kim, S.-J., Woo, S.H., Noda, T., ... Yamauchi, H. (2012a). Possible roles of rutin in buckwheat plant. The European Journal of Plant Science and Biotechnology, 6, 37-42.

Suzuki, T., Mukasa, Y., Morishita, T., Takigawa, S., Noda, T. (2012b). Traits of shattering resistant buckwheat 'W/SK86GF'. Breeding Science, 62, 360-364. doi:10.1270/jsbbs.62.360

Suzuki, T., Morishita, T., Mukasa, Y., Takigawa, S., Yokota, S., Ishiguro, K., Noda, T. (2014). Breeding of 'Manten-Kirari', a non-bitter and trace-rutinosidase variety of Tartary buckwheat (Fagopyrum tataricum Gaertn.). Breeding Science, 64, 344-350. doi:10.1270/jsbbs.64.344

Woo, S.-H., Kamal, A.H.M., Suzuki, T., Campbell, C.G., Adachi, T., Yun, Y.H., ...Choi, J.S. (2010). 
Buckwheat (Fagopyrum esculentum Moench): concepts, prospects and potential. The European Journal of Plant Science and Biotechnology, 4, 1-16.

Yabe, S., Hara, T., Ueno, M., Enoki, H., Kimura, T., Nishimura, S., ... Iwata, H. (2014). Rapid genotyping with DNA micro-arrays for high-density linkage mapping and QTL mapping in common buckwheat (Fagopyrum esculentum Moench). Breeding Science, 64, 291-299. doi:10.1270/jsbbs.64.291
Yasui, Y., Wang, Y., Ohnishi, O., Campbell, C.G. (2004). Amplified fragment length polymorphism linkage analysis of common buckwheat (Fagopyrum esculentum) and its wild self-pollinated relative Fagopyrum homotropicum. Genome, 47, 345-351.

Yasui, Y., Hirakawa, H., Ueno, M., Matsui, K., KatsubeTanaka, T., Yang, S.J., Mori, M. (2016). Assembly of the draft genome of buckwheat and its applications in identifying agronomically useful genes. DNA Research, 23, 215-224. doi:10.1093/dnares/dsw012 